DOI: 10.20472/EFC.2021.015.008

\author{
DINIS SANTOS \\ Faculty of Economics of the University of Coimbra, Portugal \\ PAULO GAMA \\ Faculty of Economics of the University of Coimbra, Portugal
}

\title{
IS INSIDER TRADING SUCCESSFUL? AN EXTENSIVE ANALYSIS WITH BUYING AND SELLING EVIDENCE
}

\begin{abstract}
:
Purpose: The goal of the present study is to first, understand the market timing capabilities of a set of internal stakeholders while trading (buying and selling) stock, and second, shed some light on some of the characteristics that make them (or not) successful.

Design/methodology/approach: We use a relative transaction price approach (RTP) on 842 aggregated trades coming from insiders. These were taken from publicly disclosed information available on the Portuguese regulator. Furthermore, we use a median regression-based method to infer on our conclusions.

Findings: We find that insiders buy (sell) at a relatively lower (higher) price when compared to other traders. This shows signs of market timing capabilities. Furthermore, from the studied characteristics, neither the frequency nor gender are good predictors for performance, but the seniority in the organization can help us to understand that some insiders, mostly on the managerial level, might have an edge. Overall, we also find that insiders' trades made OTC generally overperform the ones made on the open market. At last, we find that insiders did not lose any performance during the Portuguese bailout period.

Originality/value: By using a thorough analytical approach and a never-used sample of trading data, comprising both buying and selling trades at high-frequency (daily) level, we build on the literature of insider trading as well as on the knowledge around the effects of trading on the open market vs. OTC. We also make yet another contribute towards the literature around the Portuguese bailout effect.
\end{abstract}

\section{Keywords:}

Insider trading, Opportunistic Behavior, Market Timing, Undervaluation, Insiders' characteristics; Gender performance

JEL Classification: G14, G15 


\section{Purpose}

The goal of the present study is to first, understand the market timing capabilities of a set of internal stakeholders while trading (buying and selling) stock, and second, shed some light on some of the characteristics that make them (or not) successful.

\section{Design/methodology/approach}

We use a relative transaction price approach (RTP) on 842 aggregated trades coming from insiders. These were taken from publicly disclosed information available on the Portuguese regulator. Furthermore, we use a median regression-based method to infer on our conclusions.

\section{Findings}

We find that insiders buy (sell) at a relatively lower (higher) price when compared to other traders. This shows signs of market timing capabilities. Furthermore, from the studied characteristics, neither the frequency nor gender are good predictors for performance, but the seniority in the organization can help us to understand that some insiders, mostly on the managerial level, might have an edge. Overall, we also find that insiders' trades made OTC generally overperform the ones made on the open market. At last, we find that insiders did not lose any performance during the Portuguese bailout period.

\section{Originality/value}

By using a thorough analytical approach and a never-used sample of trading data, comprising both buying and selling trades at high-frequency (daily) level, we build on the literature of insider trading as well as on the knowledge around the effects of trading on the open market vs. OTC. We also make yet another contribute towards the literature around the Portuguese bailout effect. 


\section{Introduction}

There has always been a special curiosity about understanding how insiders are able to time the market while making (or not) use of privileged information. More than understanding if they time the market, it is also important to identify differences across the insiders' pool.

This paper focus not only on insider stakeholders trading performance while both, buying and selling stock, but also on analyzing a set of intrinsic characteristics that can influence their performance. Complementary, we also control performance by analyzing their behavior on the open market vs. over the counter as well as in the event of a macroeconomic shift.

In more detail, our work starts by extending a dataset 1 introduced by Santos and Gama (2019) when studying own stock trading performance by firms. In the current paper, we extend the data broadness by include data on internal stakeholder trading. For this, we took a run on analyzing PDF documents disclosed to the $\mathrm{CMVM}^{2}$ which are complete with original, unfiltered transactional data.

Here, and although we tried to exactly match the specs of the initial dataset, the final enhanced dataset ranges on a slightly smaller time horizon (2010-2015 vs. 2007-2015) as the available observations do not extend as far as we would consider optimal. Nonetheless, the range of covered firms increased. This is true as although not all listed firms traded own stock within the analysis period, more stakeholders (coming from a broader set of firms) engaged in private trading activity. As such, and after aggregation of all daily observations, we ended up with a robust dataset comprising 837 aggregated daily observations across 38 firms.

Methodology wise, we follow a relative transaction price approach by establishing event-date and benchmark specific windows (with different lengths, both centered and forward looking) similarly to Santos and Gama (2019;2020) but now with a focus on insiders' trades.

Regarding some of the insiders' characteristics, we classify insiders by gender, seniority, and eagerness to trade measured by the trading frequency. More on our rationale can be found in the next sections.

A few last remarks, when studying the impact of major economic shift on the insiders' trading performance, we include the Portuguese economic bailout ${ }^{3}$ of 2011 as a benchmark event. Here it is important to state that in mid-2011 Portugal was under great scrutiny from European Institutions, and although the scrutiny was on an institutional level, one might thing that there could be a performance spill-over effect to the private trader (see Santos and Gama

\footnotetext{
${ }^{1}$ Initially focusing on own stock transactions including firms repurchase and reselling operations, the authors fist used a set of 821 individual disclosure documents, totaling for 33 firms (which comprises the full universe of firms which traded and reported within the analysis timeframe), with data ranging from January 2005 to March 2015 and accounting for 37997 transactions.

2 The Portuguese Securities Market Commission (CMVM), established in April 1991 focus on supervising and regulating securities and other financial instruments and the activity of all those interact within said markets. http://www.cmvm.pt/en/Pages/homepage.aspx

${ }^{3}$ The bailout period can be identified as having started in April 2011 (Fernandes, Gama and Vieira, 2016).
} 
$(2019,2010)$ for more insights on the bailout effect on the firm's ability to time the market). Our main results are the following:

Firstly, we found that insiders buy (sell) at a relatively lower (higher) price when compared to other traders. This shows signs of market timing capabilities which are stronger when we look at a weekly time window. On the aggregate, when bridging insiders' results with firms own stock trading results studied by Santos and Gama (2019) as well as Dittmar and Field (2015), we verify that they go hand in hand in terms of performance, especially when looking at the buying activity. Interestingly and focusing on the selling, insiders even overperform firms as Santos and Gama (2019) show.

Secondly, we found that insiders have powerful forecasting skills. They can accurately identify profitable periods to trade both from a buying and selling perspectives. This is completely aligned with the literature e.g. Georgen et al, (2019).

Thirdly, and now focusing on characteristics, we found that contrarily to the literature (Inci et al, 2019), we do not show any statistically significant different on the performance of women and men while trading. This was clear both on buying and selling transaction across all the RTP lengths.

Furthermore, and regarding the eagerness to trade measured by the insiders' trading frequency, we did not find great differences across the three main clusters (infrequent, moderate, and frequent). Here, although we could follow Fishman and Kathleen (1992)' theory, which defends that the more insider trade, the more efficient are the stock prices, and thus, less opportunity, we found that because all insiders are good at market timing, the frequency is not so important. One can say that, they can trade in bulk or by performing more frequent smaller trades with very similar overperformance results.

Still, and now focusing on the insiders' role within the organization, while expanding on the work of Hillier et al, (2015), we show that insiders on more "Senior Administration" related roles are less capable of timing the market. Thus, if we use seniority as a proxy for age and maturity, we can understand that these stakeholders are more interested in the long-term value of the firm and not the shorter horizon profits from an individual perspective. Thus, younger, and more eager stakeholders (such as managers) will be more interested in capitalizing their knowledge.

Fourthly, we show that trades made over the counter prove more profitable while buying and selling. This is aligned with our expectations as these trades go through a dealer network rather than through a formal exchange and the dealer directly connects buyers and sellers, generating asymmetries when benchmarking with transaction on open market.

Fifthly, we show that there are no statistically significant differences on the performance of trades made before and after the bailout and this is expected as at this time, the pressure and scrutiny was increased at an institutional level having little to no impact on the individual level. Thus, no specific pressure (besides psychology) was made to individuals as entities. 
Sixthly, and at last, when looking at buying activity seasonality we noticed that, although scattered, the months between April and August (except for June) seem more favorable. This can be explained as normally stock turnover is significantly lower during the summer (Hong et al, 2009). On a quick note, regarding the selling activity, our data proved not significant for differences while studying seasonality. The sample distribution was very homogeneous across all the months.

The remainder of this paper is organized as follows: Section 2 reviews the most relevant literature; Section 3 describes the sample, the data-collection process and the calculation procedures; Section 4 presents and discusses the empirical results; and in Section 5, conclusions are drawn.

\section{Literature review}

There are several definitions of insider trading, and specificities naturally vary across markets and market regulation. However, as an overarching rule, insider trading can be defined as the buying or selling of stock leveraging information known only by the trader or a small number of people.

More specifically one can say that insider trading can be performed by a specific group of stakeholders, such as company officers, directors, or others that hold a specific percentage of the firm equity and are in the possession of privileged information (for the specific case of Portugal, please refer to art. $378 .^{\circ}, \mathrm{n} .^{\circ} 3$ of CdVM for a complete definition of privileged information and to article $248 .^{\circ}, \mathrm{n}^{\circ} 1$ do CdVM for the mandatory disclosure property of such information).

Within this framework of using privileged information, insider trading is tendentially badly perceived for many reasons. Initially thought to be destructive towards fair competition and provider of negative influence towards the free market making it economically inefficient and immoral (Werhane, 1989; Scheppele, 1993; McGee, 2008), one can say that although intuitively easy to define as a negative activity, it is hard to do the same via law-and-economics (Scheppele, 1993).

Nevertheless, after decades of advances in regulation we are now in a position where researchers argue about stirps of insider trading that can be beneficial to the investment community (McGee, 2008).

Furthermore, one can defend that insider trading practices can expand to outside of the own firm stock by leverage other company or industry specific knowledge. Although this is not the focus of our research, it is worth mentioning that authors such as Georgen et al, (2019) share evidence on how networks of both executives and non-executives leverage non-firm specific information in order to obtain profitable transactions. As such, connections play an important role in external insider trading practices.

Nonetheless, there is a thin line in between the must's and the do's, and as such, many times this information is not timely reported proving precious to achieve profitable transaction for insiders.

There is a large body of research targeting the type of information insiders leverage and when to leverage. As an example, recently Cziraki et al, (2019) focused on analyzing insider 
repurchase transactions taken before corporate disclosures and that end up reflecting changes on fundamentals such as cost of capital and operating performing. Clearly insiders are taking advantage of misevaluation.

Also, importantly, we must acknowledge that insider trading can prove profitable depending on many characteristics. A simple example can be drawn by the sheer way shareholders define their investment horizons. On this topic and Fu et al, (2020) try to connect different holding horizons with insiders' performance. As such, several hypothesis have been discussed, some authors defend that short shareholder investment horizons can intensify the level of information asymmetry and therefore improve the insider traders position due to investors pressuring management for short term result (Harford et al, 2018; Graham et al, 2008; $\mathrm{Fu}$ et al, 2020). Furthermore, it is also defended that, firms that have more long-term investors focusing on value tend to eliminate information asymmetry along time (Boone and White, 2015; Fu et al, 2020). Thus, based on the logical concept that more information asymmetry provides insiders with informational advantages, insiders will be able to use these advantages to maximize their profits (Kyle, 1985; Biggerstaffet al, 2020; Cline et al, 2017; Fu et al, 2020). Moreover, this is correlated to an opportunistic trading behavior which are classified as more informed (Cohen et al, 2012; Fu et al, 2020)

It is also fair to say that the level persistency of the informational advantage of insiders pays a crucial role on their adherence of long or short trading strategies. Insiders will therefore opt by dilute their trading strategies when they are in the possession of more persistent informational advantages and opt for short term trading when their informational advantage is likely to vanish quickly. Moreover, insiders also tend to try and decrease the rate of decay of informational advantage in order to extend their trading horizon (Biggerstaf et al, 2020).

We have now proof that insider trades do incorporate non-public information regarding the firm's future performance which is therefore transmitted to the public information pool (e.g., Ke et al., 2003; Piotroski and Roulstone, 2005; Fu et al, 2020). This is true, even in the event that insiders don't have precise data but realize that there is mispricing (Seyhun, 1992; Jenter, 2005; Piotroski and Roulstone 2005; Cziraki et al, 2019)

From here, one as to ask what is the impact of insider trading on other third-party players?

It is also important to state that, by achieving these results, insiders have an influence on not only the immediate stock prices by shaping demand and supply at the present time, but also on analyst forecasts.

We all understand that analysts normally focus only on publicly available information such as financial statements, voluntary disclosures and other management sourced information in order to provide their forecasts that are accurate depending on the degree of knowledge and transparency of information. However, non-public information, such as the one used by insider to promote insider trading, might have a clear impact on the reliability of these forecasts.

On this topic, He and Marginson (2020) analyzed how the role of financial analysts, while providers of forecasts, are influenced by the works of insider traders. For starters, the authors defend that insider trades increase the amount of available information and therefore supporting more accurate forecasts and a lower relative cost (the cost of gathering and processing information). Moreover, this also has a secondary effect which is related to the highest processing capability of analysts vs. investors. Here, because investors have a lower 
capability of processing insider trading information, they will increase the trust on analyst coverage and therefore there will be a higher demand for this service (He and Marginson, 2020).

Slightly deeper on detail, the authors also defend that purchasing operations, which are perceived as operations driven when there is a good outlook for the firm, are more informative than sales and therefore have a stronger impact on analyst coverage (He and Marginson, 2020).

While reflecting on insider trading activity, some researchers were able to defend that decision making and performance are clearly driven by individual skills and abilities. thus, depending on the insiders' profile, including personality and psychological fit, a certain amount of bias such as overconfidence, optimism or limited attention will be generated. Such bias will play a strong role when it comes to the performance of their trades. The same was studied regarding their attitudes towards risk and willingness to use privileged information (Hillier et al, 2015).

Consequently, and because different firms are created by different people with different characteristics, it is important to study if indeed insider traders work in a pattern system and what are the different types of insiders... Thus, we aim to understand who are they? What is their patter? And if it is possible to predict their behavior? This, always bearing in mind the studied behavior reflects only trades on the personal portfolio of managers and not on their firm's portfolio.

On a specific note to our approach on insider trading performance, we understand that specific characteristics of insiders are not always easily accessible. However, we aim to identify traits that shed light on intrinsic characteristics, which evolve over time. These will include gender, age proxied by tenure/maturity and eagerness to trade. This might help us to establish the extent to which there is a variation in the relative transaction prices depending on the targeted insider. We also aim to include controls transaction type (open market vs. OTC), macroeconomic shifting event and at last seasonality.

We ground ourselves in a vast set of literature. For instance, other researchers such as Hillier et al, (2015) which produced very robust results, and contribute to the literature by including a study approach and set of dimensions.

As a final remark, it is worth to consider that our work was inspired by other authors such as Ataullah et al, (2018) which provide us an anchor point as they also emphasized the role of optimism and overconfidence when evaluating managerial behavior as well as Kallunki et al, (2009) which focus more on a wealth perspective. The later analyze into what extent the salary, holdings (internal and external) and tax framework of insiders play as motive to their decision to buy and sell.

Summing up, by performing this study, we aim to contribute to the literature in terms of understanding if insiders are in-fact able to overperform the market, moreover and on the aggregate, if they are able to overperform their own employees while trading own stock, and if there are differences across different types of stakeholders. More specifically, gender, maturity and eagerness driven differences. 


\section{Research Design}

As traditionally, the goal of this section is to introduce the data used throughout our empirical work as well as to shed some light on the transformations such as the procedure to derive the relative transaction price, the derived frequency classification criteria, as well as the insider characteristics which we looked at. After this, we put forward our main hypothesis.

\subsection{Data collection}

In order to study the performance of insiders and insider trading patterns by looking at some of their characteristics, we focused on extending a dataset ${ }^{4}$ introduced by Santos and Gama (2019) when studying own stock trading. As such, extending the data broadness to include data on internal stakeholder trading, we took a chance analyzing PDF documents disclosed to the $\mathrm{CMVM}^{5}$ which are complete with original.

Here, and although we tried to exactly match the specs of the initial dataset, the final enhanced dataset ranges on a slightly smaller time horizon (2010-2015 vs. 2007-2015) as the available observations do not extend as far as we would consider optimal. Nonetheless, the range of covered firms increased. This is true as although not all listed firms traded own stock within the analysis period, more stakeholders (coming from a broader set of firms) engaged in private trading activity.

Furthermore, another important remark is that in order to deal with the high frequency of operations (intra-daily ${ }^{6}$ ) from the same stakeholder, aggregation was done by computing ${ }^{7}$ the weighted average daily trade price. This was made separately for buy and sale trades in the open market or over the counter. For consistency, we followed the same approach as Santos and Gama (2019; 2020) (See annex I).

One last undertaken effort was to address human error on disclosing. Thus, we filtered the data for outlier prices, misdating of operations as well as market opening incoherence regarding the stipulated trading calendar. We therefore readjusted all historical data to all capital events occurring from the disclosing date until the present analysis date. Capital change events with an adjustment factor different from zero were considered in this task. The outcome of this procedure was a robust dataset of 837 aggregated daily observations for studying internal stakeholder's trading behavior across 38 firms.

\footnotetext{
${ }^{4}$ Initially focusing on own stock transactions including firms repurchase and reselling operations, the authors fist used a set of 821 individual disclosure documents, totaling for 33 firms (which comprises the full universe of firms which traded and reported within the analysis timeframe), with data ranging from January 2005 to March 2015 and accounting for 37997 transactions.

5 The Portuguese Securities Market Commission (CMVM), established in April 1991 focus on supervising and regulating securities and other financial instruments and the activity of all those interact within said markets. http://www.cmvm.pt/en/Pages/homepage.aspx

6 Original PDF files can disclose trading data trade-by-trade (high frequency), or daily aggregated, or even aggregated by order (which may be executed in several different trades). Aggregating data daily allows for comparing all different scenarios

7 PHP programing (Hypertext Preprocessor) was used to process the aggregation tasks more efficiently.
} 


\subsection{Relative transaction price}

The Relative Transaction Prices (or RTP) approach, as in Santos and Gama (2019; 2020), focus on comparing the average trading price paid (received) by an internal stakeholder during a specific period, the trade price (TP), and a pre-defined benchmark, the benchmark price (BP).

Following the methodology used in the calculation of the average daily trade price, we use daily frequency data to compute trade prices for 5-day and 22-day length time windows ${ }^{8}$ (both centered and forward looking) in order to compute the benchmark prices.

Thus, because the RTP always compares the trade price to a benchmark. This ratio signal allows to assess the performance of the internal stakeholders' trades.

On one hand, when the trade price is insignificantly different from the benchmark price, the insider stakeholder shows neutral performance. On the other hand, if there are statistically significant differences between the average trade price and the benchmark price, which may be negative or positive, we assume that the insider stakeholder performed better (worse) than other traders, making them able (unable) to time the market and potentially signaling insider trading practices. For a more specific methodology on the calculation of the Relative Transaction Prices please see annex I-B.

\subsection{Discussing intrinsic characteristics}

In order to understand potential patterns across the trades being analyzed we decided to study few characteristics amongst the different subjects covered in the sample

First, and incentivized by the literature, we classify insiders by gender in order to understand if in our analysis context, men, on average are still able to engage in more profitable trades when compared to women (Inci et al, 2019).

Second, and in order to understand the role of seniority, we cluster the roles of all the internal stakeholders that engaged in trading operations in to two main categories. Senior administration and managerial level. The reason to proceed as such was to subjectively homogenize the different roles and titles existing in different structure and size organizations. As such, we use these two main stakeholder clusters as a proxy for seniority/maturity and bearing in mind that typically seniority comes with age, we can therefore extend our inference. As such, we hope to add on the work of Hillier et al, (2015), while exploring the impact of personal attributes on corporate insider trading.

Third is the eagerness to trade. Here we clustered the stakeholders on three categories, infrequent, moderate and frequent traders, in here and according to Fishman and Kathleen (1992), the more insider trade, the more efficient are the stock prices. Thus, by this rationale,

\footnotetext{
${ }^{8}$ Here and differently from Santos and Gama $(2019 ; 2020)$, we chose not to use a quarterly benchmark (66-day length) due to the differences in sample magnitude.
} 
higher frequency traders should have less profitable returns as they are constantly providing information to the market and reducing asymmetry.

On this note, it is important to state that after analyzing the sample distribution, we classified frequent traders as the ones that trade 10 times or more per year, infrequent traders the ones that trade 3 times or less per year, and moderate traders from 4 to nine times.

\subsection{Sample description}

For a better understanding of the sample, and focusing on the calculated relative transaction prices, on table 1 we present a brief description. Here, and totaling at 842 aggregated daily observations we have a split across four distinct types of transactions.

Overall, we present data on both buy and sell transactions ranging from 2010 to 2015 where $66 \%$ are buys and the remaining are sales. Furthermore, we also have a fair split of open market vs. over the counter where $83 \%$ of all transactions are made on the Euronext and the remaining OTC.

Table 1: Transaction type sample description

\begin{tabular}{ccccccc}
\hline & Year & $\begin{array}{c}\text { Trades } \\
\text { number }\end{array}$ & & \multicolumn{2}{c}{ Transactions (daily) } & \multicolumn{2}{c}{ Market } \\
\cline { 3 - 7 } & & Buy & Sale & $\begin{array}{c}\text { Open } \\
\text { Market }\end{array}$ & OTC \\
\cline { 3 - 7 } & & $65 \%$ & $35 \%$ & $64 \%$ & $36 \%$ \\
\hline $\mathbf{2 0 1 0}$ & 207 & $90 \%$ & $10 \%$ & $81 \%$ & $19 \%$ \\
\hline $\mathbf{2 0 1 1}$ & 184 & $87 \%$ & $13 \%$ & $87 \%$ & $13 \%$ \\
\hline $\mathbf{2 0 1 2}$ & 127 & $44 \%$ & $56 \%$ & $94 \%$ & $6 \%$ \\
\hline $\mathbf{2 0 1 3}$ & 85 & $42 \%$ & $58 \%$ & $94 \%$ & $6 \%$ \\
\hline $\mathbf{2 0 1 4}$ & 198 & 41 & $56 \%$ & $44 \%$ & $95 \%$ & $5 \%$ \\
\hline Total & 842 & $66 \%$ & $34 \%$ & $83 \%$ & $17 \%$ \\
\hline
\end{tabular}

Source: Authors' Calculations.

This table presents the number of observations after daily aggregation available for each year between 2010 and 2015, regarding all the distinct types of transactions; buy, and sales as well as Open Market Vs. OTC.

Furthermore, table 2 shares some light on the spit across the different groupings of the studied trade characteristics. Overall, and looking at the full 2010-to-2015-time horizon, our sample shows $9 \%$ of all the trades being performed by women, this split can be perhaps influenced by the gender discrimination in high profile roles. Nonetheless, it still provides us valuable insights on 76 aggregated trades.

Furthermore, we see a split of 78 to $22 \%$ when it comes to the proxy for seniority (meaning the internal stakeholder's role). At last, and regarding the eagerness to trade proxied by the frequency, we report that infrequent traders are the most common (around 53\%), followed by 
frequent ones (around 34\%). The remaining are internal stakeholders that trade in a moderate manner (around 12\%).

Table 2: Characteristics sample description

\begin{tabular}{|c|c|c|c|c|c|c|c|c|c|}
\hline \multirow[t]{2}{*}{ Year } & \multirow{2}{*}{$\begin{array}{l}\text { Trades } \\
\text { number }\end{array}$} & \multicolumn{2}{|c|}{ Role within firm } & \multicolumn{2}{|c|}{ Gender } & \multicolumn{4}{|c|}{ Total number of traders } \\
\hline & & $\begin{array}{c}\text { Administration } \\
\text { level }\end{array}$ & $\begin{array}{c}\text { Managerial } \\
\text { Level }\end{array}$ & Women & Men & $\mathbf{N}$ & $\begin{array}{c}\text { Frequent } \\
\%\end{array}$ & $\begin{array}{c}\text { Moderate } \\
\% \\
\end{array}$ & $\begin{array}{c}\text { Infrequent } \\
\%\end{array}$ \\
\hline 2010 & 207 & $72 \%$ & $28 \%$ & $4 \%$ & $96 \%$ & 96 & $73 \%$ & $11 \%$ & $16 \%$ \\
\hline 2011 & 184 & $80 \%$ & $20 \%$ & $14 \%$ & $86 \%$ & 54 & $37 \%$ & $16 \%$ & $47 \%$ \\
\hline 2012 & 127 & $83 \%$ & $17 \%$ & $0 \%$ & $100 \%$ & 46 & $39 \%$ & $21 \%$ & $40 \%$ \\
\hline 2013 & 85 & $84 \%$ & $16 \%$ & $7 \%$ & $93 \%$ & 38 & $65 \%$ & $14 \%$ & $21 \%$ \\
\hline 2014 & 198 & $74 \%$ & $26 \%$ & $9 \%$ & $91 \%$ & 67 & $54 \%$ & $7 \%$ & $39 \%$ \\
\hline 2015 & 41 & $88 \%$ & $12 \%$ & $7 \%$ & $93 \%$ & 16 & $46 \%$ & $0 \%$ & $54 \%$ \\
\hline Total & 842 & $78 \%$ & $22 \%$ & $7 \%$ & $93 \%$ & & $53 \%$ & $12 \%$ & $34 \%$ \\
\hline
\end{tabular}

This table presents the number of observations after daily aggregation available for each year between 2010 and 2015, regarding the role segmentation (Administration level vs. Managerial level) as well as gender. It also presents the number of internal stakeholders that traded in each year and the \% distribution of them classified as Infrequent, moderate and frequent by each year.

This classification is based on the daily transaction count available in each year. As such, frequent traders as the ones that trade 10 times or more per year, in frequent traders the ones that trade 3 times or less per year, and moderate traders from 4 to nine times.

\subsection{Summarizing our base case hypothesis}

As previously discussed, in order to achieve our research goals we use internal stakeholder transaction-based disclosed information in order to build relative transaction prices (which benchmark against the market) and thus to infer if these stakeholders are indeed able to time the market and obtain abnormal returns, thus indicating potential use of privileged information.

Furthermore, we want to dig deeper and understand if there are differences across these internal stakeholders and if characteristics such as gender, maturity (proxied by role) and eagerness to trade (proxied by frequency) are influencers of their performance.

At last, we aim to analyze if market specific differences (open market vs. OTC) play a role in the performance of the internal stakeholder's transactions, as well as if trades made after the Portuguese bailout prove more of less profitable.

As such, we put forward the following general hypothesis to help structuring some (but not limiting) of our findings.

H1: Overall, insider stakeholders will prove to be able to time the market by performing over profitable trades (both buy and sell). 
This provides a bilateral perspective. Note that we include different benchmark periods across the study. These allow to investigate market timing from a past performance or future expectations perspectives.

- H2: Different internal stakeholders with different characteristics will showcase different levels of market timing capabilities on both their buying and selling activity.

- H2a: On average, men are still able to engage in more profitable trades when compared to women.

- H2b: More senior stakeholders (Administration level) will have lower relative performance while to time the market.

- H2c: Higher frequency traders should have lower market timing capabilities and thus less profitable results.

As such, we will be able to support the literature on better understanding the differences and patterns on market timing from an insider stakeholder perspective, and thus how likely are specific stakeholders to incur on insider trading practices.

- H3: Trading over the counter provides a better set-up for insider stakeholders in order to time the market

This hypothesis is taken since over-the-counter transactions go through a dealer network rather than through a formal exchange. Thus, differences on market timing capabilities are expected. Partially due to the dealer that directly connects buyers and sellers, generating asymmetries when benchmarking with transaction on open market

- H4: Trades made after the bailout will not prove less profitable.

The base for this hypothesis is that regulation and scrutiny across the Portuguese landscape increased substantially after the Portuguese bailout. Nonetheless, this scrutiny was increased at an institutional level having little to no impact on the individual level. The only impact could be from a psychological level in terms of carefulness as a protection mechanism, although we expect it to be minimal.

\section{Empirical results and discussion}

In this section, we present the results of each one of our analyses, firstly, at an aggregate level, secondly, looking at the insider stakeholder's characteristics as well as the controls for over the counter as well as after the bailout period, and thirdly the seasonality results.

\subsection{Aggregate Results}

Table 3 presents the mean and median RTP results. Since we do not know the distribution pattern of the relative transaction prices, we applied the Shapiro -Wilk W test for normality to the different RTP's samples first. The results of the tests presented in Table 3 show that neither, the buy or the sell, samples followed a normal distribution. Therefore, these results support our decision to use medians instead of averages as a measure for comparing performance throughout the remainder of this work. 
Table 3: Aggregate results

\begin{tabular}{|c|c|c|c|c|c|}
\hline \multicolumn{6}{|c|}{ Panel A: Centered RTPs } \\
\hline \multicolumn{6}{|c|}{ Panel A1: Buying Activity } \\
\hline & $\begin{array}{l}\text { Mean } \\
\text { RTP }\end{array}$ & $\begin{array}{c}\text { Shapiro -Wilk } \\
\text { W }\end{array}$ & Median RTP & $\begin{array}{l}\text { Wilcoxon Signed- } \\
\text { Rank Test z }\end{array}$ & $\begin{array}{c}\text { Statistical } \\
\text { significance }\end{array}$ \\
\hline RTP -0 to 0 & -0.0363797 & $0.000 * * *$ & 0 & -8.077 & $0.000 * * *$ \\
\hline ST: RTP -5 to 5 & -0.0386733 & $0.000 * * *$ & -0.017382 & -9.201 & $0.000 * * *$ \\
\hline MT: RTP -22 to 22 & -0.0457748 & $0.000 * * *$ & -0.0094049 & -10.072 & $0.000 * * *$ \\
\hline \multicolumn{6}{|c|}{ Panel A2: Selling Activity } \\
\hline RTP -0 to 0 & 0.2481628 & $0.000 * * *$ & 0 & 3.448 & $0.006 * * *$ \\
\hline ST: RTP -5 to 5 & 0.2510311 & $0.000 * * *$ & 0.009502 & 6.728 & $0.000 * * *$ \\
\hline MT: RTP -22 to 22 & 0.2594378 & $0.000 * * *$ & 0.0154237 & 7.329 & $0.000 * * *$ \\
\hline \multicolumn{6}{|c|}{ Panel B: Forward-looking RTPs } \\
\hline \multicolumn{6}{|c|}{ Panel B1: Buying Activity } \\
\hline & $\begin{array}{l}\text { Mean } \\
\text { RTP }\end{array}$ & $\begin{array}{c}\text { Shapiro-Wilk } \\
\text { W }\end{array}$ & Median RTP & $\begin{array}{l}\text { Wilcoxon Signed- } \\
\text { Rank Test z }\end{array}$ & $\begin{array}{c}\text { Statistical } \\
\text { significance }\end{array}$ \\
\hline ST: RTP 0 to 5 & -0.0371444 & $0.000 * * *$ & -0.0081744 & -7.100 & $0.000 * * *$ \\
\hline MT: RTP 0 to 22 & -0.0363808 & $0.000 * * *$ & -0.0068281 & -6.008 & $0.000 * * *$ \\
\hline \multicolumn{6}{|c|}{ Panel B2: Selling Activity } \\
\hline ST: RTP 0 to 5 & 0.2503463 & $0.000 * * *$ & 0.0067315 & 4.895 & $0.000 * * *$ \\
\hline MT: RTP 0 to 22 & 0.2589843 & $0.000 * * *$ & 0.0086244 & 4.584 & $0.000 * * *$ \\
\hline
\end{tabular}

Source: Authors' Calculations.

This table presents the Mean and Median Results for the Relative Transaction Prices corresponding to the all the selected transactions and benchmarks (indicated in column 1). Panel A focuses on centered RTPs and panel B on forward-looking RTPs. RTP stands for Relative Transaction Price. -5 to 5 and -22 to 22,0 to 5 and 0 to 22 stand for the time interval of the benchmark used in the calculation, that is, centered or forward-looking benchmarks, respectively. The Shapiro -Wilk W test for normality was used to test data distribution. Median statistical significance levels were calculated with recourse to the Wilcoxon Signed Rank. P-values are presented in italics. $* * *, * *$ and $*$ show statistical significance at a level of 1,5 and $10 \%$, respectively.

Panel A1 of Table 2 presents the results for the centered benchmarks and buying activity. On the aggregate, the results show that, regarding the buying activity, we find negative median RTPs and therefore proof of market timing capabilities when it comes to internal stakeholders buying their firm's stock. The price these paid for transactions when compared to other traders was indeed smaller. This is true for both the quarterly, and weekly benchmarks. In an effort to analyze the high frequency trade capacity (on a daily level), here they showed no market timing capabilities.

Furthermore, the weekly median RTP presented the greatest negative result (RTP = 0.017382), suggesting better market timing skills at a shorter benchmark time period, rather than at the longest benchmarking period. If we do a high level comparison with the results found by Santos and Gama (20019) as well as Dittmar and Field (2015) when analyzing at the market timing capabilities of firms while trading own stock, we find that insiders show the same level of performance in their private trades as the their employers (firms) did while repurchasing own stock. 
Panel A2 of Table 2 presents the results for the centered benchmarks and selling activity. Here, with the exception of the short-term (intraday) window, where there is no evidence of over (or under) performance, we showcase that insiders are actually selling their stock at a relatively higher price when compared to other traders in the market. This is especially interesting if we compare with the results of Santos and Gama (2019) where the authors found that firms reselling own stock are not able to time the market, thus we show that insiders, when performing private trades, outperform even their own firm institutional trading activity which can suggest the use of privileged information to optimize their timing when compared to a corporate and third-party perspectives.

We also questioned ourselves on the forecasting skills of these insiders while buying and selling their firm's stock from a private perspective. Therefore, Panel B1 of Table 2 presents the results concerning the forward-looking benchmarks and buying activity. The results are aligned with the centered benchmarks. Both in the weekly and monthly RTP show evidence of market timing capabilities. Panel B2 of Table 2 presents the results concerning the forward-looking benchmarks and selling activity. Again, we have the same results confirming not only market timing capabilities while looking at past and present info but also looking to a more extended horizon. Thus, clearly insiders show accurate forecasting skills at all benchmarks periods when deciding to buy or sell stock of their current firm from a private perspective. This is completely aligned with the literature e.g. Georgen et al, (2019).

Within this first set of results, we find that, while buying and selling, insiders are indeed able to time the market. This is valid looking at centered or forward-looking benchmarks making turning the findings even more robust.

Overall, and not accounting for applied methodologies, our results also support the findings of Kyle (1985), Biggerstaffet al, (2020), Cline et al, (2017), Fu et al, (2020). Moreover, and restating our literature review, it is worth to state that this trading behavior and performance might have its genesis on a better-informed position (Cohen et al, 2012; Fu et al, 2020).

Moreover and parallelly looking at the extended literature which focuses on analysis firms buying and selling overperformance through the recognition of undervaluation as well as information asymmetry from Ikenberry (1996), Stephens and Weishbach (1998), Ikenberry, Lakonishok and Vermaelen (2000), Chan Ikenberry and Lee (2004) and Bonaimé and Ryngaert (2013). We can mention that one ca defend undervaluation as the main reason for the existance of market timing capabilities. Thus, we can easily make the bridge from a firms' perspective to

a private trading insider with the same level of information available. In the end, the firm is the sum of its parts, and human capital are the most important of these part.

\subsection{Internal stakeholder's characteristic and subsample analysis}

To complement our market timing analysis, and in order to have a better understanding of which types of stakeholders are better at timing the market, we focused on analyzing insider 
specific characteristics. These are the gender, maturity (proxied by the role) and eagerness to trade (proxied by the trading frequency).

As such, and in order to do so, we built-up a median regression model where we introduced set of dummy variables to account for each of the tested characteristics. This was made separately for buy and sell operations, and we also included a control for trades made over the counter as well as a control for trades made after the bailout.

Thus, the complete model is computed as follows:

$$
\begin{gathered}
\text { RTP }_{i t}=\alpha+\beta_{1} \text { Women }_{i t}+\beta_{2} \text { Frequent }_{i t}+\beta_{3} \text { Infrequent }_{i t}+\beta_{4} \text { Adminitration }_{i t}+ \\
+\beta_{5} \text { OverTheCounter }+\beta_{6} \text { AfterBailout }_{i t}+\mu_{i t}(1)
\end{gathered}
$$

Where, $R T P_{i t}-$ Stands for the Relative Transaction Price for each benchmark; $\alpha-$ is the model constant; $\beta_{n}$-is the coefficient coming from the respective regressor; Women is a dummy variable turning 1 if the transaction is made by a female trader; Frequent is a dummy variable turning 1 if the transaction is made by insider stakeholders which are classified as frequent traders and 0 otherwise; Infrequent is a dummy variable turning 1 if the transaction is made by insider stakeholders which are classified as infrequent and 0 otherwise (we included both frequent and infrequent to control for moderate traders); Afterbailout is a dummy variable turning 1 if the transaction is made after the bailout and; OTC is a dummy variable turning 1 if the transaction is made over the counter and $\mu_{i t}$ is the error term.

In this model, increases in the market timing capabilities are measured in negative (positive) impacts on the buy (sell) related RTP's.

Table 4 shows our results. Here, we show that some trader-specific characteristics do influence the market-timing capabilities by impacting the specific RTPs.

\begin{tabular}{|c|c|c|c|c|c|c|}
\hline & \multicolumn{3}{|c|}{ Panel A: Buying Activity } & \multicolumn{3}{|c|}{ Panel B: Selling Activity } \\
\hline & RTP -0 to 0 & RTP -5 to 5 & RTP -22 to 22 & RTP -0 to 0 & RTP -5 to 5 & RTP -22 to 22 \\
\hline Women & $\begin{array}{c}0.0031128 \\
(0.418)\end{array}$ & $\begin{array}{c}0.0034546 \\
(0.663)\end{array}$ & $\begin{array}{c}-0.0143579 \\
(0.161)\end{array}$ & $\begin{array}{c}0 \\
\text { (N/A) }\end{array}$ & $\begin{array}{c}0 \\
(\mathrm{~N} / \mathrm{A})\end{array}$ & $\begin{array}{c}0.0089983 \\
(0.957)\end{array}$ \\
\hline Frequent & $\begin{array}{c}0 \\
\text { (N/A) }\end{array}$ & $\begin{array}{c}0.0018071 \\
(0.770)\end{array}$ & $\begin{array}{c}0.0051623 \\
(0.518)\end{array}$ & $\begin{array}{c}0 \\
(\mathrm{~N} / \mathrm{A})\end{array}$ & $\begin{array}{c}0 \\
(\mathrm{~N} / \mathrm{A})\end{array}$ & $\begin{array}{c}0.0028699 \\
(0.988)\end{array}$ \\
\hline Infrequent & $\begin{array}{c}0.0010793 \\
(0.743)\end{array}$ & $\begin{array}{c}0.0047188 \\
(0.483)\end{array}$ & $\begin{array}{c}0.0042119 \\
(0.628)\end{array}$ & $\begin{array}{c}0 \\
(\mathrm{~N} / \mathrm{A})\end{array}$ & $\begin{array}{c}0 \\
(\mathrm{~N} / \mathrm{A})\end{array}$ & $\begin{array}{c}0.0072266 \\
(0.968)\end{array}$ \\
\hline $\begin{array}{c}\text { Administra } \\
\text { tion role }\end{array}$ & $\begin{array}{l}0.0898367 \\
(0.000 * * *)\end{array}$ & $\begin{array}{l}0.0930866 \\
(0.000 * * *)\end{array}$ & $\begin{array}{l}0.1063327 \\
(0.000 * * *)\end{array}$ & $\begin{array}{c}0 \\
(\mathrm{~N} / \mathrm{A})\end{array}$ & $\begin{array}{c}0 \\
(\mathrm{~N} / \mathrm{A})\end{array}$ & $\begin{array}{c}-0.0016334 \\
(0.985)\end{array}$ \\
\hline $\begin{array}{l}\text { Over the } \\
\text { counter }\end{array}$ & $\begin{array}{r}-\mathbf{0 . 1 6 5 1 9 8 9} \\
(0.000 * * *) \\
\end{array}$ & $\begin{array}{c}-0.1334374 \\
(0.000 * * *)\end{array}$ & $\begin{array}{l}-0.1031028 \\
(0.000 * * *)\end{array}$ & $\begin{array}{c}0 \\
(\mathrm{~N} / \mathrm{A})\end{array}$ & $\begin{array}{c}0 \\
(\mathrm{~N} / \mathrm{A})\end{array}$ & $\begin{array}{c}0.1263567 \\
(0.331)\end{array}$ \\
\hline $\begin{array}{c}\text { After the } \\
\text { bailout }\end{array}$ & $\begin{array}{c}0.0010793 \\
(0.649)\end{array}$ & $\begin{array}{c}0.0044719 \\
(0.352)\end{array}$ & $\begin{array}{c}0.0056448 \\
(0.364)\end{array}$ & $\begin{array}{c}0 \\
(\mathrm{~N} / \mathrm{A})\end{array}$ & $\begin{array}{c}0 \\
(\mathrm{~N} / \mathrm{A})\end{array}$ & $\begin{array}{c}-0.0190012 \\
(0.859)\end{array}$ \\
\hline Const & $\begin{array}{l}\mathbf{- 0 . 0 9 0 9 1 6} \\
(0.000 * * *)\end{array}$ & $\begin{array}{r}-\mathbf{0 . 1 0 3 7 6 9 7} \\
\left(0.000^{* * *}\right)\end{array}$ & $\begin{array}{l}-\mathbf{0 . 1 2 0 0 0 2 2} \\
(0.000 * * *)\end{array}$ & $\begin{array}{c}0 \\
(\mathrm{~N} / \mathrm{A})\end{array}$ & $\begin{array}{c}0 \\
(\mathrm{~N} / \mathrm{A})\end{array}$ & $\begin{array}{c}0.0207586 \\
(0.922)\end{array}$ \\
\hline $\begin{array}{c}\text { Pseudo } \\
R^{\wedge} 2\end{array}$ & 0.3409 & 0.2617 & 0.2231 & (N/A) & (N/A) & 0.0463 \\
\hline
\end{tabular}

Table 4: General buy vs. sell centered benchmarks 
Source: Authors Calculations.

This table presents in Panel A (Panel B) the median regressions for the buying (sell) activity over both the chosen characteristics within the sample as well as some control variables (OTC, and after bailout). The aim of the estimation is to define evidence of specific characteristics linked to overperformance while trading. RTP stands for Relative Transaction Price and -5 to $5,-22$ and 22 stands for the time interval of the benchmark used in the calculation giving us centered relative transaction prices. Heteroskedasticity and autocorrelation robust standard errors are used. $* * *, * *$ and $*$ show statistical significance at a level of 1,5 and $10 \%$, respectively.

Regarding each of our variables and focusing first on the gender, contrarily to the literature (Inci et al, 2019), we do not show any statistically significant different on the performance of women and men while trading. This was clear both on buying and selling transaction across all the RTP lengths (both centered and forward-looking - table 5).

Table 5: General buy vs. sell forward looking benchmarks

\begin{tabular}{|c|c|c|c|c|}
\hline & \multicolumn{2}{|c|}{$\begin{array}{c}\text { Panel A: Buying } \\
\text { Activity }\end{array}$} & \multicolumn{2}{|c|}{$\begin{array}{c}\text { Panel B: Selling } \\
\text { Activity }\end{array}$} \\
\hline & RTP 0 to 5 & RTP 0 to 22 & RTP 0 to 5 & RTP 0 to 22 \\
\hline Women & $\begin{array}{c}0.0013313 \\
(0.881)\end{array}$ & $\begin{array}{c}0.0073581 \\
(0.407)\end{array}$ & $\begin{array}{c}0 \\
\text { (N/A) }\end{array}$ & $\begin{array}{c}0.0020012 \\
(0.991)\end{array}$ \\
\hline Frequent & $\begin{array}{c}-0.0033767 \\
(0.626)\end{array}$ & $\begin{array}{c}0.0053454 \\
(0.440)\end{array}$ & $\begin{array}{c}0 \\
(\mathrm{~N} / \mathrm{A})\end{array}$ & $\begin{array}{c}0.0291747 \\
(0.885)\end{array}$ \\
\hline Infrequent & $\begin{array}{c}0.0029664 \\
(0.694)\end{array}$ & $\begin{array}{l}\mathbf{0 . 0 2 0 3 2 4 2} \\
(0.007 * * *)\end{array}$ & $\begin{array}{c}0 \\
\text { (N/A) }\end{array}$ & $\begin{array}{c}0.0236461 \\
(0.901)\end{array}$ \\
\hline $\begin{array}{l}\text { Administra } \\
\text { tion role }\end{array}$ & $\begin{array}{l}0.0755746 \\
(0.000 * * *)\end{array}$ & $\begin{array}{r}\mathbf{0 . 0 8 3 7 2 6 5} \\
(0.000 * * *)\end{array}$ & $\begin{array}{c}0 \\
(\mathrm{~N} / \mathrm{A})\end{array}$ & $\begin{array}{c}-0.0038016 \\
(0.967)\end{array}$ \\
\hline $\begin{array}{l}\text { Over the } \\
\text { counter }\end{array}$ & $\begin{array}{r}-0.1541406 \\
(0.000 * * *)\end{array}$ & $\begin{array}{r}-\mathbf{0 . 1 5 8 0 8 0 5} \\
(0.000 * * *)\end{array}$ & $\begin{array}{c}0 \\
(\mathrm{~N} / \mathrm{A})\end{array}$ & $\begin{array}{c}0.1374166 \\
(0.309)\end{array}$ \\
\hline $\begin{array}{c}\text { After the } \\
\text { bailout }\end{array}$ & $\begin{array}{c}0.0006398 \\
(0.906)\end{array}$ & $\begin{array}{c}0.0012799 \\
(0.812)\end{array}$ & $\begin{array}{c}0 \\
\text { (N/A) }\end{array}$ & $\begin{array}{c}-0.0374367 \\
(0.736)\end{array}$ \\
\hline Const & $\begin{array}{r}-\mathbf{0 . 0 7 6 6 7 7 1} \\
(0.000 * * *) \\
\end{array}$ & $\begin{array}{c}-\mathbf{0 . 0 9 2 0 2 2} \\
(0.000 * * *)\end{array}$ & $\begin{array}{c}0 \\
(\mathrm{~N} / \mathrm{A})\end{array}$ & $\begin{array}{c}0.0135966 \\
(0.951) \\
\end{array}$ \\
\hline $\begin{array}{l}\text { Pseudo } \\
\mathbf{R}^{\wedge} 2\end{array}$ & 0.2617 & 0.2402 & $\begin{array}{c}0 \\
(\mathrm{~N} / \mathrm{A})\end{array}$ & 0.0602 \\
\hline
\end{tabular}

Source: Authors Calculations.

This table presents in Panel A (Panel B) the median regressions for the buying (sell) activity over both the chosen characteristics within the sample as well as some control variables (OTC, and after bailout). The aim of the estimation is to define evidence of specific characteristics linked to overperformance while trading. RTP stands for Relative Transaction Price and -5 to $5,-22$ and 22 stands for the time interval of the benchmark used in the calculation giving us forward looking relative transaction prices. Heteroskedasticity and autocorrelation robust standard errors are used. $* * * * *$ and $*$ show statistical significance at a level of 1,5 and $10 \%$, respectively.

Furthermore, and regarding the eagerness to trade measured by the insiders' market frequency, we also do not show great differences across the three main clusters (infrequent, moderate, and frequent). Here, although we could follow Fishman and Kathleen (1992) theory, which defends that the more insider trade, the more efficient are the stock prices, and thus, less opportunity, we found that because all insiders are good at market timing, the frequency is not so important. Oversimplifying it, they can trade in bulk or by performing more frequent smaller 
trades with very similar overperformance results. Our own exception is the underperformance of infrequent trades while buying when looking at the monthly forward-looking RTP (0.0203242).

Now, when looking at the role within the organization, we expand the literature, and more concretely the work of Hillier et al, (2015), by providing evidence that insiders on more "Senior Administration" related roles are less capable to time the market. Now, on a purely speculative manner, if we use seniority as a proxy for age and maturity, we can understand that these stakeholders are more interested in the long-term value of the firm and not the shorter horizon profits from an individual perspective. Thus, it is not hard to imagine that younger, and more eager stakeholders such as managers will be more interested in "capitalizing" their knowledge. The evidence supporting this theory is true for buying transactions at all length RTPs both centered and forward-looking, with its higher impact being on the intraday centered RPT (0.1651989), which again suggests private use of information in the very short-term.

Thus, from here, we conclude that from the studied characteristics, neither the frequency nor gender are good predictors for performance, but the seniority in the organization is. A quick remark is that, again, we focus on managerial and upwards seniority (as we are not suggesting results would be similar when studying a junior level insider).

Now moving on to our controls and starting first by analyzing the impact on the market on which the transaction was made, when looking into table 4 and 5, we clearly see that trades made over the counter prove more profitable for insiders while buying and selling (this at any benchmarked horizon). This goes together with our initial hypothesis as these trades go through a dealer network rather than through a formal exchange and the dealer directly connects buyers and sellers, generating asymmetries when benchmarking with transaction on open market.

Finally, when looking at our after-bailout control, and understanding that in mid-2011 Portugal was under great scrutiny from European Institutions, we still show that this scrutiny and change did not impact the individual trading performance of insiders. There are no statistically significant differences on the performance of trades made before and after the bailout and this is expected as this scrutiny was increased at an institutional level having little to no impact on the individual level. Thus, no specific pressure (besides psychology) was made to individuals as entities.

\subsection{Seasonality}

In this section, we look at seasonal effects on the distribution of median RTP.

Are there better months for timing the market? That is, do insiders achieve different results conditional on the month of trading? If so, we collected evidence on the effect of seasonality on market timing skills.

For this, we estimate by OLS, separately for buying and selling activity, a pooled regression on the medians using the RTPs as dependent variables and monthly dummies as independent variables. 
To deal with collinearity we did not included all monthly dummies in the model; we decided to drop May from the analysis due to its lower number of observations and thus reducing the loss of data. The model equation is as follows:

$$
\begin{gathered}
\text { RTP }_{i t}=\alpha+\beta_{1} \text { January }_{i t}+\beta_{2} \text { February }_{i t} \\
+\beta_{3} \text { March }_{i t}+\beta_{4} \text { April }_{i t}+\beta_{5} \text { June }_{i t}+\beta_{6} \text { July }_{i t}+\beta_{7} \text { August }_{i t}+\beta_{8} \text { September }_{i t} \\
\beta_{9} \text { October }+\beta_{10} \text { November }_{i t}+\beta_{11} \text { December }_{i t}
\end{gathered}
$$

Where, $R T P_{i t}$ - Stands for the Relative Transaction Price for each benchmark; $\alpha-$ is the model constant; $\beta_{n}$ - is the coefficient coming from the respective regressor; the monthly regressors are dummy variables which take the value 1 if the trade is made on the specific month and 0 otherwise.

As such, increases in the market timing capabilities of insiders are measured in negative (positive) impacts on the buy (sale)-related RTPs. As a reminder, because our data distribution follows a non-normal fit, we use a quantile regression on the medians.

As such, table 6 and 7 presents the results (centered and forward-looking RPTs

\begin{tabular}{|c|c|c|c|c|c|c|}
\hline & \multicolumn{3}{|c|}{ Panel A: Buy Activity } & \multicolumn{3}{|c|}{ Panel B: Sell Activity } \\
\hline & RTP 0 to 0 & RTP -5 to 5 & RTP -22 to 22 & RTP 0 to 0 & RTP -5 to 5 & RTP -22 to 22 \\
\hline January & $\begin{array}{c}-.006074 \\
\left(0.0376981^{* *}\right)\end{array}$ & $\begin{array}{c}-\mathbf{0 . 0 0 5 6 0 4 2} \\
(0.0401029 * *)\end{array}$ & $\begin{array}{l}0.0004125 \\
(0.050293)\end{array}$ & $\begin{array}{c}0 \\
(\mathrm{~N} / \mathrm{A})\end{array}$ & $\begin{array}{c}0 \\
(\mathrm{~N} / \mathrm{A})\end{array}$ & $\begin{array}{c}0 \\
(\mathrm{~N} / \mathrm{A})\end{array}$ \\
\hline February & $\begin{array}{c}0 \\
(.0428459 * *) \\
\end{array}$ & $\begin{array}{l}-\mathbf{- 0 . 0 0 9 4 3 8 2} \\
(0.0350671)\end{array}$ & $\begin{array}{c}0.0202609 \\
(0.0691077)\end{array}$ & $\begin{array}{c}0 \\
\text { (N/A) }\end{array}$ & $\begin{array}{c}0 \\
\text { (N/A) }\end{array}$ & $\begin{array}{c}0 \\
\text { (N/A) }\end{array}$ \\
\hline March & $\begin{array}{c}-0.264425 \\
(-0.2260607)\end{array}$ & $\begin{array}{c}-0.2635219 \\
(-0.2236218)\end{array}$ & $\begin{array}{c}-.2392577 \\
(-0.1954653)\end{array}$ & $\begin{array}{c}0 \\
\text { (N/A) }\end{array}$ & $\begin{array}{c}0 \\
(\mathrm{~N} / \mathrm{A})\end{array}$ & $\begin{array}{c}0 \\
\text { (N/A) }\end{array}$ \\
\hline April & $\begin{array}{c}-0.0019582 \\
(0.0429094 * *)\end{array}$ & $\begin{array}{c}-\mathbf{0 . 0 1 5 7 1 2} \\
(0.0311539 * *)\end{array}$ & $\begin{array}{c}-0.0376643 \\
(0.0137734 * *)\end{array}$ & $\begin{array}{c}0 \\
(\mathrm{~N} / \mathrm{A})\end{array}$ & $\begin{array}{c}0 \\
(\mathrm{~N} / \mathrm{A})\end{array}$ & $\begin{array}{c}0 \\
(\mathrm{~N} / \mathrm{A})\end{array}$ \\
\hline June & $\begin{array}{c}-.0001154 \\
(0.042319 * *) \\
\end{array}$ & $\begin{array}{c}-\mathbf{0 . 0 0 5 8 3 4 2} \\
(\mathbf{0 . 0 3 8 2 5 1 6} * *) \\
\end{array}$ & $\begin{array}{c}0.0103698 \\
(0.0587561 *) \\
\end{array}$ & $\begin{array}{c}0 \\
(\mathrm{~N} / \mathrm{A})\end{array}$ & $\begin{array}{c}0 \\
(\mathrm{~N} / \mathrm{A})\end{array}$ & $\begin{array}{c}0 \\
\text { (N/A) }\end{array}$ \\
\hline July & $\begin{array}{c}0 \\
(0.0422399 * *) \\
\end{array}$ & $\begin{array}{c}0.000823 \\
\left(0.0449088^{* *}\right) \\
\end{array}$ & $\begin{array}{c}0.0093628 \\
\left(0.0577491^{*}\right)\end{array}$ & $\begin{array}{c}0 \\
(\mathrm{~N} / \mathrm{A})\end{array}$ & $\begin{array}{c}0 \\
(\mathrm{~N} / \mathrm{A})\end{array}$ & $\begin{array}{c}0 \\
(\mathrm{~N} / \mathrm{A}) \\
\end{array}$ \\
\hline August & $\begin{array}{c}0 \\
(0.0440283 * *)\end{array}$ & $\begin{array}{c}-0.0122391 \\
(.0334679 * *)\end{array}$ & $\begin{array}{c}-0.0111131 \\
(0.0390528 * *)\end{array}$ & $\begin{array}{c}0 \\
(\mathrm{~N} / \mathrm{A})\end{array}$ & $\begin{array}{c}0 \\
(\mathrm{~N} / \mathrm{A})\end{array}$ & $\begin{array}{c}0 \\
(\mathrm{~N} / \mathrm{A})\end{array}$ \\
\hline September & $\begin{array}{c}0 \\
(.0426363 * *)\end{array}$ & $\begin{array}{c}-\mathbf{0 . 0 0 8 1 7 6} \\
(0.0363293 * *)\end{array}$ & $\begin{array}{c}0.0057622 \\
(0.054609 *)\end{array}$ & $\begin{array}{c}0 \\
(\mathrm{~N} / \mathrm{A})\end{array}$ & $\begin{array}{c}0 \\
(\mathrm{~N} / \mathrm{A})\end{array}$ & $\begin{array}{c}0 \\
(\mathrm{~N} / \mathrm{A})\end{array}$ \\
\hline October & $\begin{array}{c}0 \\
(0.063039 *)\end{array}$ & $\begin{array}{c}0.0036896 \\
(0.0648873 *)\end{array}$ & $\begin{array}{c}0.0106163 \\
(0.0777839 *)\end{array}$ & $\begin{array}{c}0 \\
(\mathrm{~N} / \mathrm{A})\end{array}$ & $\begin{array}{c}0 \\
(\mathrm{~N} / \mathrm{A}) \\
\end{array}$ & $\begin{array}{c}0 \\
(\mathrm{~N} / \mathrm{A}) \\
\end{array}$ \\
\hline November & $\begin{array}{c}0 \\
(0.0445753 * *)\end{array}$ & $\begin{array}{c}-0.0016108 \\
(0.0449459 * *)\end{array}$ & $\begin{array}{c}0.0114898 \\
(0.0625882 *)\end{array}$ & $\begin{array}{c}0 \\
(\mathrm{~N} / \mathrm{A})\end{array}$ & $\begin{array}{c}0 \\
(\mathrm{~N} / \mathrm{A}) \\
\end{array}$ & $\begin{array}{c}0 \\
(\mathrm{~N} / \mathrm{A})\end{array}$ \\
\hline December & $\begin{array}{c}0 \\
\left(0.0409051^{* *}\right) \\
\end{array}$ & $\begin{array}{c}-0.002492 \\
(0.0398814 * *)\end{array}$ & $\begin{array}{c}-\mathbf{0 . 0 0 7 5 3 1 7} \\
(0.0389752 * *)\end{array}$ & $\begin{array}{c}0 \\
(\mathrm{~N} / \mathrm{A})\end{array}$ & $\begin{array}{c}0 \\
(\mathrm{~N} / \mathrm{A})\end{array}$ & $\begin{array}{c}0 \\
(\mathrm{~N} / \mathrm{A}) \\
\end{array}$ \\
\hline Const & $\begin{array}{c}0 \\
\left(0.0315195^{* *}\right)\end{array}$ & $\begin{array}{c}-0.0013688 \\
(0.0313428 * *)\end{array}$ & $\begin{array}{c}0.017915 \\
\left(0.0179876^{* *}\right)\end{array}$ & $\begin{array}{c}0 \\
(\mathrm{~N} / \mathrm{A})\end{array}$ & $\begin{array}{c}0 \\
(\mathrm{~N} / \mathrm{A})\end{array}$ & $\begin{array}{c}0 \\
(\mathrm{~N} / \mathrm{A})\end{array}$ \\
\hline Pseudo $R^{\wedge} 2$ & 0.0668 & 0.0504 & 0.0626 & (N/A) & (N/A) & (N/A) \\
\hline
\end{tabular}
respectively).

\section{Table 6: Centered benchmark - Seasonality Assessment}


Source: Authors Calculations.

This table presents in Panel A (Panel B) the median regressions for the Buy (Sell) operations over the dummy variables for each month within the sample. At the sample level, the month of May was chosen as the drop variable due to its smaller number of observations, thus avoiding collinearity in the regression. The aim of the estimation is to find seasonality evidence. RTP stands for Relative Transaction Price and -5 to 5 and -22 to 22 for the time interval of the benchmark used in the calculation giving us centered relative transaction prices. Heteroskedasticity and autocorrelation robust standard errors are used. $* * * * *$ and $*$ show statistical significance at a level of 1,5 and $10 \%$, respectively.

We find that, for the buying activity, and although scattered, results are more favorable between April and August (with the exception of June) were our regression coefficient proved more powerful within these months (a higher negative value for the buying activity), thus, throughout these months insiders show higher capabilities of timing the market when compared to third party traders.

This can be explained as normally stock turnover is significantly lower during the summer (Hong et al, 2009). On a quick note, regarding the selling activity, our data proved not significant for differences while studying seasonality. The sample distribution was very homogeneous across all the months.

Table 7: Forward looking benchmark - Seasonality Assessment

\begin{tabular}{|c|c|c|c|c|}
\hline & \multicolumn{2}{|c|}{ Panel A: Buy Activity } & \multicolumn{2}{|c|}{ Panel B: Sell Activity } \\
\hline & RTP 0 to 5 & RTP 0 to 22 & RTP 0 to 5 & RTP 0 to 22 \\
\hline January & $\begin{array}{c}-0.0022172 \\
\left(0.0526177^{*}\right)\end{array}$ & $\begin{array}{c}-0.0051929 \\
(0.0425064 * *)\end{array}$ & $\begin{array}{c}0 \\
(\mathrm{~N} / \mathrm{A})\end{array}$ & $\begin{array}{c}0 \\
(\mathrm{~N} / \mathrm{A})\end{array}$ \\
\hline February & $\begin{array}{c}0.0044451 \\
(0.0581437 *)\end{array}$ & $\begin{array}{c}-0.004956 \\
(0.0415057 * *)\end{array}$ & $\begin{array}{c}0 \\
(\mathrm{~N} / \mathrm{A})\end{array}$ & $\begin{array}{c}0 \\
(\mathrm{~N} / \mathrm{A})\end{array}$ \\
\hline March & $\begin{array}{c}-0.2502459 \\
(-0.2021038)\end{array}$ & $\begin{array}{c}-0.2656532 \\
(-0.2239298)\end{array}$ & $\begin{array}{c}0 \\
(\mathrm{~N} / \mathrm{A})\end{array}$ & $\begin{array}{c}0 \\
(\mathrm{~N} / \mathrm{A})\end{array}$ \\
\hline April & $\begin{array}{c}-0.0020844 \\
(0.0544624 *)\end{array}$ & $\begin{array}{c}-0.0178571 \\
(0.031036 * *)\end{array}$ & $\begin{array}{c}0 \\
(\mathrm{~N} / \mathrm{A})\end{array}$ & $\begin{array}{c}0 \\
(\mathrm{~N} / \mathrm{A})\end{array}$ \\
\hline June & $\begin{array}{c}0.0100231 \\
\left(0.0632155^{*}\right)\end{array}$ & $\begin{array}{c}-0.0071256 \\
(0.038904 * *)\end{array}$ & $\begin{array}{c}0 \\
(\mathrm{~N} / \mathrm{A})\end{array}$ & $\begin{array}{c}0 \\
(\mathrm{~N} / \mathrm{A})\end{array}$ \\
\hline July & $\begin{array}{c}0.0051217 \\
(0.0583141 *)\end{array}$ & $\begin{array}{c}0.0046174 \\
\left(0.050647^{*}\right)\end{array}$ & $\begin{array}{c}0 \\
(\mathrm{~N} / \mathrm{A})\end{array}$ & $\begin{array}{c}0 \\
(\mathrm{~N} / \mathrm{A})\end{array}$ \\
\hline August & $\begin{array}{c}-\mathbf{0 . 0 3 1 9 9 3 8} \\
(0.0231548 * *)\end{array}$ & $\begin{array}{c}\mathbf{- 0 . 0 1 5 3 8 3 8} \\
\left(0.0323155^{* *}\right)\end{array}$ & $\begin{array}{c}0 \\
(\mathrm{~N} / \mathrm{A})\end{array}$ & $\begin{array}{c}0 \\
(\mathrm{~N} / \mathrm{A})\end{array}$ \\
\hline September & $\begin{array}{c}0.0013679 \\
\left(0.0550665^{*}\right)\end{array}$ & $\begin{array}{c}-0.004984 \\
(0.0414776 *)\end{array}$ & $\begin{array}{c}0 \\
(\mathrm{~N} / \mathrm{A})\end{array}$ & $\begin{array}{c}0 \\
(\mathrm{~N} / \mathrm{A})\end{array}$ \\
\hline October & $\begin{array}{c}(0.0140565) \\
\left(0.0878956^{*}\right)\end{array}$ & $\begin{array}{c}0.0099306 \\
\left(0.0736124^{*}\right)\end{array}$ & $\begin{array}{c}0 \\
(\mathrm{~N} / \mathrm{A})\end{array}$ & $\begin{array}{c}0 \\
(\mathrm{~N} / \mathrm{A})\end{array}$ \\
\hline November & $\begin{array}{c}.0056115 \\
\left(0.0617853^{*}\right)\end{array}$ & $\begin{array}{c}-0.0041206 \\
(0.044454 *)\end{array}$ & $\begin{array}{c}0 \\
(\mathrm{~N} / \mathrm{A})\end{array}$ & $\begin{array}{c}0 \\
(\mathrm{~N} / \mathrm{A})\end{array}$ \\
\hline December & $\begin{array}{c}(0.0054939) \\
\left(0.0566201^{*}\right)\end{array}$ & $\begin{array}{c}-\mathbf{0 . 0 0 4 8 0 4 4} \\
(0.0394627 * *)\end{array}$ & $\begin{array}{c}0 \\
(\mathrm{~N} / \mathrm{A})\end{array}$ & $\begin{array}{c}0 \\
(\mathrm{~N} / \mathrm{A})\end{array}$ \\
\hline Const & $\begin{array}{c}-0.0062112 \\
\left(0.0332575^{* *}\right)\end{array}$ & $\begin{array}{c}0 \\
(0.0343474 * *)\end{array}$ & $\begin{array}{c}0 \\
(\mathrm{~N} / \mathrm{A})\end{array}$ & $\begin{array}{c}0 \\
(\mathrm{~N} / \mathrm{A})\end{array}$ \\
\hline Pseudo $\mathbf{R}^{\wedge} 2$ & 0.0599 & 0.0612 & (N/A) & (N/A) \\
\hline
\end{tabular}


Source: Authors Calculations.

This table presents in Panel A (Panel B) the median regressions for the Buy (Sell) operations over the dummy variables for each month within the sample. At the sample level, the month of May was chosen as the drop variable due to its smaller number of observations, thus avoiding collinearity in the regression. The aim of the estimation is to find seasonality evidence. RTP stands for Relative Transaction Price and 0 to 5 and 0 to 22 for the time interval of the benchmark used in the calculation giving us forward-looking relative transaction prices. Heteroskedasticity and autocorrelation robust standard errors are used. $* * * * *$ and $*$ show statistical significance at a level of 1,5 and $10 \%$, respectively.

Looking at the forward-looking RTPs (table 7 below), our results seem confirmed also from a perspective of looking ahead. As in the centered benchmarks, April to August were on average (with the except of July) the stronger months when it comes to outperform the market.

\section{Conclusions}

The present study uses a relative transaction price approach to study a never-used sample of trading data, comprising both buying and selling trades from insider stakeholders of Portuguese firms. It also includes trades made on the open market and over the counter.

Our dataset comprises 842 aggregated stock trades that were taken by publicly disclosed information to the Portuguese regulator.

Overall, regarding to the buying activity, we found that insider stakeholders buy at a relatively lower price when compared to other traders. This shows signs of market timing capabilities. Interestingly, the weekly time window showcases best results. On the aggregate, when bridging insiders' results with firms own stock trading results studied by Santos and Gama (20019) as well as Dittmar and Field (2015), we verify that they go hand in hand in terms of performance. Basically, insider stakeholder's show the same level of performance in their private trades as the firms did while repurchasing own stock.

When looking at the selling activity, with the exception of the short-term (intraday) window, where there is no evidence of over (or under) performance, we showcase that insiders are actually selling their stock at a relatively higher price when compared to other traders in the market. This is especially interesting if we compare with the results of Santos and Gama (2019) where the authors found that firms reselling own stock are not able to time the market, thus we show that insiders, when performing private trades, outperform even their own institutional trading activity which can suggest the use of privileged information to optimize their timing when compared to a corporate and third-party perspective.

When moving away from centered benchmark and focusing on the forecasting skills of insider stakeholders, we show that insiders can accurately identify profitable periods to trade both from a buying and selling perspectives. This is completely aligned with the literature e.g. Georgen et al, (2019).

Overall, these results support the findings of Kyle (1985), Biggerstaffet al, (2020), Cline et al, (2017), Fu et al, (2020). Moreover, and restating our literature review, this trading behavior 
and performance might have its genesis on a better-informed position (Cohen et al, 2012; Fu et al, 2020). Moreover if we extend the perspective of information asymmetry and undervaluation from a firm market timing perspective to the insider stakeholder perspective, we are thus aligned with Ikenberry (1996), Stephens and Weishbach (1998), Ikenberry, Lakonishok and Vermaelen (2000), Chan Ikenberry and Lee (2004) and Bonaimé and Ryngaert (2013 as these authors defend that undervaluation as the main reason for market timing capabilities.

But more than understanding about insiders' trading and their market timing capabilities, we also focused on understanding some of the characteristics that drive these capabilities. These could be intrinsic to the insider, such as gender, maturity (measured by the organizational role) and eagerness to trade (measured by their trading frequency) or external such as the period (before or after the Portuguese bailout) or market in which they trade (open market vs. OTC).

As such, and after analyzing our data, we found that contrarily to the literature (Inci et al, 2019), we do not show any statistically significant different on the performance of women and men while trading. This was clear both on buying and selling transaction across all the RTP lengths. Furthermore, and regarding the eagerness to trade measured by the insiders' market frequency, we also do not show great differences across the three main clusters (infrequent, moderate, and frequent). Here, although we could follow Fishman and Kathleen (1992) theory, which defends that the more insider trade, the more efficient are the stock prices, and thus, less opportunity, we found that because all insiders are good at market timing, the frequency is not so important. Oversimplifying it, they can trade in bulk or by performing more frequent smaller trades with very similar overperformance results. Our own exception is the underperformance of infrequent trades while buying and looking at the monthly forward-looking RTP.

Furthermore, and focusing on the insiders' role within the organization, we expand the literature, and more concretely the work of Hillier et al, (2015), by providing evidence that insiders on more "Senior Administration" related roles are less capable of timing the market. Now, on a purely speculative manner, if we use seniority as a proxy for age and maturity, we can understand that these stakeholders are more interested in the long-term value of the firm and not the shorter horizon profits from an individual perspective. Thus, it is not hard to visualize that younger, and more eager stakeholders such as managers will be more interested in capitalizing their knowledge.

Thus, we conclude that from the studied intrinsic characteristics, neither the frequency nor gender are good predictors for performance, but the seniority in the organization can help us to understand that some insiders, mostly on the managerial level, might have an edge. A quick remark, that can be seen as a study limitation, is that we focus on managerial and upwards seniority (as we are not suggesting results would be similar when studying a junior level insider).

Moving away from the intrinsic characteristics of insiders, when we analyzed the impact on the market on which they trade, we show that trades made over the counter prove more profitable while buying and selling (this at any benchmarked horizon). Once again, this is according to expectations as these trades go through a dealer network rather than through a 
formal exchange and the dealer directly connects buyers and sellers, generating asymmetries when benchmarking with transaction on open market.

Also, and bearing in mind that Portugal suffered a bailout followed by great scrutiny from European institutions in mid-2011, we still show that this scrutiny and pressure did not impact the individual trading performance of insiders. There are no statistically significant differences on the performance of trades made before and after the bailout and this is expected as this scrutiny was increased at an institutional level having little to no impact on the individual level. Thus, no specific pressure (besides psychology) was made to individuals as entities.

At last, we made a final assessment in order to look for seasonal effects. Although results were mainly scattered, we noticed that, for the buying activity, the months between April and August (except for June) seem more favorable. This can be explained as normally stock turnover is significantly lower during the summer (Hong et al, 2009). As a final remark, regarding the selling activity, our data proved not significant for differences while studying seasonality. The sample distribution was very homogeneous across all the months.

With this work, we build on the literature of insider trading as well as on the knowledge around the effects of trading on the open market vs. OTC. We also make another contribute towards the literature around the Portuguese bailout effect.

\section{References}

Ayyagari, M., Demirgüç-Kunt, A., \& Maksimovic, V. (2012). Financing of firms in developing countries: lessons from research. World Bank Policy Research Working Paper, (6036).

Ataullah, A., Vivian, A., \& Xu, B. (2018). Time-varying managerial overconfidence and corporate debt maturity structure. The European Journal of Finance, 24(2), 157-181.

Biggerstaff, L., Cicero, D., \& Wintoki, M. B. (2020). Insider trading patterns. Journal of Corporate Finance, 101654.

Bonaime, A. A., \& Ryngaert, M. D. (2013). Insider trading and share repurchases: Do insiders and firms trade in the same direction?. Journal of Corporate Finance, 22, 35-53.

Boone, A. L., and J. T. White, 2015, "The effect of institutional ownership on firm transparency and information production”, Journal of Financial Economics 117(3), 508533.

Chan, K., Ikenberry, D., \& Lee, I. (2004). Economic sources of gain in stock repurchases. Journal of Financial and quantitative Analysis, 461-479.

Cline, B., S. Gokkaya, and X. Liu, 2017, "The Persistence of Opportunistic Insider Trading”, Financial Management 46, 919-964.

Cohen, L., C. Malloy, and L. Pomorski, 2012, “Decoding Inside Information”, Journal of Finance 67 (3), 1009-1044.

Fernandes, C., Gama, P. M., \& Vieira, E. (2016). Does local and Euro area sentiment matter 
for sovereign debt markets? Evidence from a bailout country. Applied Economics, 48(9), 816-834.

Fishman, M. J., \& Hagerty, K. M. (1992). Insider trading and the efficiency of stock prices. The RAND Journal of Economics, 106-122.

Fu, X., Kong, L., Tang, T., \& Yan, X. (2020). Insider trading and shareholder investment horizons. Journal of Corporate Finance, 62, 101508.

Graham, J., S. Li, and J. Qiu, 2008, "Corporate Misreporting and Bank Loan Contracting," Journal of Financial Economics 89, 44- 61

Goergen, M., Renneboog, L., \& Zhao, Y. (2019). Insider trading and networked directors. Journal of Corporate Finance, 56, 152-175.

Gurnani, S., 2016. The financial crisis in Portugal: austerity in perspective.

Ikenberry, D.L. and Vermaelen, T., 1996. The option to repurchase stock. Financial Management, pp.9-24.

Ikenberry, D., Lakonishok, J., \& Vermaelen, T. (2000). Stock repurchases in Canada: Performance and strategic trading. The Journal of Finance, 55(5), 2373-2397.

Harford, J., A. Kecskés, and S. Mansi, 2018, "Do Long-Term Investors Improve Corporate Decision Making?” Journal of Corporate Finance, 50, 424-452.

He, G. and Marginson, D. (2020) 'The impact of insider trading on analyst coverage and forecasts.', Accounting research journal., 33 (3). pp. 499-521.

Hillier, D., Korczak, A., \& Korczak, P. (2015). The impact of personal attributes on corporate insider trading. Journal of Corporate Finance, 30, 150-167.

Hong, H., \& Yu, J. (2009). Gone fishin': Seasonality in trading activity and asset prices. Journal of Financial Markets, 12(4), 672-702.

Inci, A., Narayanan, M., \& Seyhun, H. (2017). Gender Differences in Executives' Access to Information. Journal of Financial and Quantitative Analysis, 52(3), 991-1016. doi:10.1017/S0022109017000266

Jenter, D., 2005. Market timing and managerial portfolio decisions, Journal of Finance 60, 1903-1949.

John, K., and L. Lang, 1991. "Insider trading around dividend announcements: Theory and evidence", Journal of Finance 46, 1361-1390.

Kallunki, J. P., Nilsson, H., \& Hellström, J. (2009). Why do insiders trade? Evidence based on unique data on Swedish insiders. Journal of Accounting and Economics, 48(1), 37-53.

Ke, B., S. Huddart, and K. Petroni, 2003, "What Insiders Know about Future Earnings and How They Use It: Evidence from Insider Trades", Journal of Accounting and Economics $35,315-346$.

Kyle, A., 1985. “Continuous Auctions and Insider Trading." Econometrica 53, 1315-1335.

Liu, Y. S. (2020). Investor sentiment, trading activity and effect of the open-market share 
repurchase based on firm characteristics. Spanish Journal of Finance and Accounting/Revista Española de Financiación y Contabilidad, 1-26.

McGee, R. W. (2008). Applying ethics to insider trading. Journal of business ethics, 77(2), 205-217.

Piotroski, J. D., and D. T. Roulstone, 2005, "Do insider trades reflect both contrarian beliefs and superior knowledge about future cash flow realizations?" Journal of Accounting and Economics 39(1), 55-81

Santos, D. D., \& Gama, P. (2019). Timing the market with own stock: an extensive analysis with buying and selling evidence. International Journal of Managerial Finance.

Santos, D., \& Gama, P. M. (2020). How do different firms perform while trading own stock? A granular analysis on specific characteristics and market conditions. International Journal of Economic Sciences, 9(2), 71-93.

Seyhun, H., 1992. Why does aggregate insider trading predict future stock returns?, Quarterly Journal of Economics 107, 1303-1331.

Scheppele, K. L. (1993). " It's Just Not Right": The Ethics of Insider Trading. Law and Contemporary Problems, 56(3), 123-173.

Stephens, C. P., \& Weisbach, M. S. (1998). Actual share reacquisitions in open-market repurchase programs. The Journal of finance, 53(1), 313-333.

Hillier, D., Korczak, A., \& Korczak, P. (2015). The impact of personal attributes on corporate insider trading. Journal of Corporate Finance, 30, 150-167.

Werhane, P. H. (1989). The ethics of insider trading. Journal of Business Ethics, 8(11), 841845. 


\section{Annex}

\subsection{Annex I}

Average daily transaction price calculation :Average Daily Transaction Price ${ }_{i}=\sum_{j=0}^{n} \frac{\text { operation Volume } e_{i, j} \times \text { operation } \text { Price }_{i, j}}{\text { Total Daily Volume Transacted }}$

procedure

Where: $i$ corresponds to each internal stakeholder, $\mathrm{j}$ identifies a specific trade, buy or sale, within each day and each market, both open and over the counter.

\subsection{Annex II}

The Relative Transaction Prices (RTP) acts as a benchmark mechanism between the average transaction prices (average sale or buying price) received or paid by the internal stakeholder during a particular period, and a chosen benchmark.

The benchmark price (BP) accounts for daily frequency and is computed considering 5day and 22-day:

$$
\text { benchmark }_{a-b}=\sum_{i=a}^{b} \frac{\text { Daily Volume }_{i} \times \text { Daily Price } \text { Close }_{i}}{\text { Total Volume }_{a-b}}
$$

Where $\mathrm{a}, \mathrm{b}= \pm 5$ or \pm 22 , and corresponds to the timeframe (in days) of the estimation window.

To calculate the Benchmark Price we use two distinct windows: centered weekly window, $\mathrm{a}=-5$ to $\mathrm{b}=+5$; centered monthly window and $\mathrm{a}=-22$ to $\mathrm{b}=+22$;

The use of event centered estimation windows helps to account for historical performance of prices and future expectations. Thus, we compute the relative transaction prices as such:

$$
\text { Relative Transaction Price }_{i, a-b}=\frac{{\text { Average Daily Operation } \text { Price }_{i}}_{\text {benchmark }_{a-b}}}{\text { Tench }}-1
$$

Where the Average Daily Operation Price $_{i}$, stands for the specific transaction day average price (see equation II) and the Benchmark $_{a-b}$ stands for the average close price in one of the earlier computed benchmarks (see equation 3 ).

We also compute forward looking RTP's by removing the past section of the benchmark windows. This is done as follows:

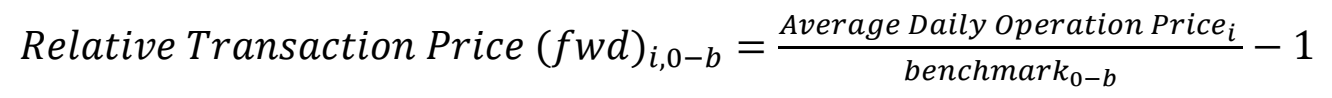

Where, once again the Average Daily Operation Price $(f w d)_{i}$, stands for the specific transaction day average price (see equation 2) and the Benchmark B $_{0-b}$ now stands for the average close price in one of the "future" benchmarks: weekly, 0 to +5 , monthly and 0 to +22 . 